\title{
Penyelesian Pembiayaan Bermasalah pada Bank Syariah
}

\author{
Madona Khairunisa \\ Universitas Islam Negeri Sultan Syarif Kasim Riau Pekanbaru \\ dona.khairunisa@gmail.com \\ Musrifah \\ Universitas Islam Negeri Sultan Syarif Kasim Riau Pekanbaru \\ Musrifah@uin-suska.ac.id
}

\begin{abstract}
Abstrak
Metode penelitian ini adalah penelitian perpustakaan, Untuk mencapai tujuan tersebut Penulis memakai metodologi penelitian bersifat kualitatif. Sumber data diperoleh langsung melalui literatur yang berkaitan dengan objek penelitian. Setelah data terkumpul dengan lengkap baru dianalisa secara deskriptif dengan metode analisis deduktif dimana data-data umum yang telah dikumpulkan ditarik kesimpulan secara khusus. Setelah dilakukan penelitian maka didapatkan kesimpulan bahwa Pola penyelesaian pembiayaan bermasalah pada Bank syariah dapat dilakukan dengan cara:1.Restrukturisasi. Restrukturisasi pembiayaan adalah salah satu upaya yang dilakukan Bank dalam kegiatan usaha penyaluran pembiayaan agar Nasabah dapat memenuhi kewajibannya kepada Bank. restrukturisasi yang dapat dilakukan adalah Penjadwalan kembali (rescheduling), Persyaratan kembali (reconditioning), Penataan kembali (restructuring), Penjadwalan kembali (rescheduling) 2. Penyelesaian melalui jaminan Penyelesaian melalui jaminan dapat dilakukan dengan cara non litigasi dan litigasi. 3.Collection Agent, dilakukan dengan menggunakan jasa pihak ketiga seperti agen/kantor hukum atau pengacara dan 4. Hapus Buku (write off) tindakan administrasi untuk menghapus buku Nasabah yang memiliki kolektibilitas macet dari neraca sebesar total tunggakan Nasabah tanpa menghapus hak tagih kepada Nasabah.
\end{abstract}

Kata Kunci: Pembiayaan Bermasalah, Restrukturisasi, Bank Syariah

\section{PENDAHULUAN}

Sebagai lembaga intermediary dan seiring dengan situasi lingkungan eksternal dan internal Perbankan yang mengalami perkembangan pesat, Bank syariah akan selalu berhadapan dengan berbagai risiko yang memiliki tingkat kompleksitas beragam dan melekat pada kegiatan usahanya. Risiko-risiko tersebut tidak dapat dihindari, tetapi dapat dikelola dan dikendalikan. Oleh karena itu, 
sebagaimana lembaga Perbankan pada umumnya, Bank syariah juga memerlukan serangkaian prosedur dan metodologi yang dapat digunakan untuk mengidentifikasi, mengukur, atau yang biasa disebut manajemen risiko (Adiwarman A Karim, 2004:255). Situasi lingkungan eksternal dan internal Perbankan mengalami perkembangan pesat yang diikuti dengan semakin kompleksnya risiko kegiatan usaha Perbankan sehingga meningkatkan kebutuhan praktik tata kelola Bank yang sehat (good corporate governance) dan penerapan manajemen risiko tersebut.

Salah satu risiko yang perlu dikendalikan dan menjadi perhatian serius pada Perbankan syariah adalah risiko kredit atau pembiayaan. Risiko kredit adalah risiko yang disebabkan oleh kegagalan counterparty dalam memenuhi kewajibannya. Risiko kredit didefenisikan sebagai risiko kerugian yang terkait dengan kemungkinan kegagalan counterparty memenuhi kewajibannya, atau risiko bahwa Nasabah mampu membayar kembali kewajibannya kepada bank (Adiwarman A Karim, 2004:260).

Secara umum pembiayaan bermasalah dalam konteks Perbankan syariah adalah pembiayaan yang dalam pelaksanaan perjanjian antara Bank syariah dengan Nasabah mengalami kendala dalam arti Nasabah mengalami kesulitan atau kegagalan melakukan pembayaran kepada Bank syariah terhadap dana yang telah disalurkan oleh Bank tersebut. Pembiayaan bermasalah (non performing financing, NPF) pada Perbankan syariah dikategorikan berdasarkan kualitas pembiayaannya masing-masing. Kualitas pembiayaan bermasalah dalam Perbankan syariah diistilahkan dengan kolektibilitas NPF. Semakin tinggi angka NPF semakin tinggi pula tingkat pembiayaan bermasalah pada Bank tersebut serta menurunkan profil risiko tingkat kesehatan Bank dimaksud.

Setiap Bank syariah tentu berharap bahwa pembiayaan-pembiayaan yang telah disalurkannya akan menjadi pembiayaan yang lancar, sehat, dan bermanfaat buat penerimanya. Namun harapan tersebut tidak selamanya akan terwujud. Adakalanya pembiayaan yang diberikan menjadi pembiayaan yang bermasalah, dimana Nasabah tidak mampu membayar kewajibannya sehingga terjadi tunggakan. Banyak faktor yang memengaruhi terjadinya pembiayaan bermasalah 
baik yang bersifat internal Nasabah maupun eksternal. Yang terpenting, Bank dapat melakukan langkah penyelamatan ketika Nasabah sudah menunjukkan gejala bermasalah, sebelum pembiayaan tersebut benar-benar menjadi pembiayaan yang bermasalah (macet) (Yusak Laksmana, 2009: 255).

Pada kajian terdahulu yang disampaikan oleh Ubaidillah dalam Jurnal elJizya vol. 6 No. 2 Juli-Desember 2018 dengan judul "Pembiayaan Bermasalah pada Bank Syariah: Strategi Penanganan dan Penyelesaiannya" disimpulkan bahwa adanya pembiayaan bermasalah pada Bank syariah secara langsung atau tidak langsung dapat memberikan dampak risiko bagi Bank itu sendiri maupun secara nasional. Dilihat dari segi produktivitasnya (performance-nya) yaitu dalam kaitannya dengan kemampuannya menghasilkan pendapatan bagi Bank, adanya pembiayaan bermasalah akan berakibat pada berkurang atau menurunnya pendapatan Bank dan bahkan mungkin sudah tidak ada lagi. Risiko lainnya adalah adanya kewajiban bagi Bank untuk memperbesar biaya pencadangan, yaitu pencadangan Penyisihan Penghapusan Aktiva Produktif (PPAP). Adanya PPAP yang besar, maka akan mengurangi produktifitas dana yang dikelola oleh Bank tersebut. Sedangkan dari segi nasional, hal tersebut akan mengurangi kontribusi Bank dalam melakukan fungsi intermediasinya sehingga tidak dapat memberikan kontribusi pada pembangunan dan pertumbuhan ekonomi. Penanggulangan pembiayaan bermasalah dapat dilakukan melalui upaya-upaya yang bersifat preventif dan upaya-upaya yang bersifat represif/kuratif. Sementara usaha penyelesaian pembiayaan macet secara garis besar dapat dilakukan melalui penyelesaian oleh Bank sendiri secara bertahap dengan pendekatan persuasif. Bila tahap pertama tersebut telah dilakukan, maka dapat digunakan langkah dan tahapan berikutnya antara lain penyelesaian melalui debt collector, penyelesaian melalui Kantor Lelang, penyelesaian melalui Badan Peradilan (al-qadha), penyelesaian melalui Badan Arbitrase (tahkim), dan penyelesaian melalui Direktorat Jenderal Piutang dan Lelang Negara (DJPLN) untuk Bank-bank BUMN (Ubaidillah, 2018: 307). 


\section{KERANGKA TEORI}

\section{Pengertian Pembiayaan}

Pembiayaan merupakan salah satu komponen dari fungsi intermediasi Bank, yaitu pemberian fasilitas penyediaan dana untuk memenuhi kebutuhan pihak-pihak yang merupakan defisit unit. Istilah pembiayaan pada dasarnya lahir dari pengertian I believe, I trust, yaitu 'saya percaya', atau 'saya menaruh kepercayaan'. Istilah pembiayaan (trust) yang berarti Bank menaruh kepercayaan kepada seseorang untuk melaksanakan amanah yang diberikan oleh Bank selaku shahibul maal (Veithzal Riva'I dan Arviyan Arifin, 2010: 698).

Pembiayaan adalah penyediaan uang atau tagihan yang dapat dipersamakan dengan itu, berdasarkan persetujuan atau kesepakatan antara Bank dengan pihak lain yang mewajibkan pihak yang dibiayai untuk mengembalikan uang atau tagihan tersebut setelah jangka waktu tertentu dengan imbalan atau bagi hasil. (Kasmir, 2006: 73)

Defenisi lain menyebutkan bahwa pembiayaan atau financing adalah pendanaan yang diberikan oleh suatu pihak kepada pihak lain untuk mendukung investasi yang telah direncanakan, baik yang dilakukan sendiri maupun lembaga. Dengan kata lain, pembiayaan adalah pendanaan yang dikeluarkan untuk mendukung investasi yang telah direncanakan. (Veithzal Riva'I dan Arviyan Arifin, 2010: 681)

Berdasarkan POJK No. 16/POJK.03/2014 tentang Penilaian Kualitas Aset Bank Umum Syariah dan Unit Usaha Syariah pembiayaan adalah penyediaan dana atau tagihan yang dipersamakan dengan itu berupa transaksi bagi hasil, transaksi sewa-menyewa termasuk sewa-menyewa jasa, transaksi jual-beli, dan transaksi pinjam-meminjam berdasarkan persetujuan atau kesepakatan antara Bank dan pihak lain yang mewajibkan pihak yang dibiayai dan/atau diberi fasilitas dana untuk mengembalikan dana tersebut setelah jangka waktu tertentu dengan imbalan ujrah, tanpa imbalan, atau bagi hasil.

Pembiayaan yang disalurkan oleh Bank Syariah merupakan salah satu aset produktif yang wajib dipantau dan dikelola pelaksanaannya berdasarkan prinsip kehati-hatian dan prinsip syariah. Penerapan prinsip kehati-hatian harus dilakukan 
guna memastikan kualitas aset pembiayaan tersebut tetap baik. Prinsip syariah adalah prinsip hukum Islam dalam kegiatan Perbankan berdasarkan fatwa yang dikeluarkan oleh Lembaga yang memiliki kewenangan dalam penetapan fatwa di bidang syariah. Penilaian atas kualitas aset produktif dalam bentuk pembiayaan ini akan menentukan apakah suatu pembiayaan akan menjadi pembiayaan bermasalah atau tidak.

\section{Penggolongan Pembiayaan}

Pembiayaan dapat digolongkan berdasarkan beberapa kriteria sebagai berikut:

\begin{tabular}{|c|c|c|c|}
\hline No. & $\begin{array}{c}\text { Kriteria } \\
\text { Penggolongan }\end{array}$ & Jenis Pembiayaan & Defenisi \\
\hline 1. & $\begin{array}{l}\text { Sifat } \\
\text { penggunaan }\end{array}$ & $\begin{array}{l}\text { b. Pembiayaan } \\
\text { produktif }\end{array}$ & $\begin{array}{l}\text { Untuk memenuhi kebutuhan konsumsi } \\
\text { berupa barang atau jasa dengan cara } \\
\text { membeli, menyewa, atau dengan cara lain } \\
\text { yang akan habis digunakan untuk memenuhi } \\
\text { kebutuhan. } \\
\text { Untuk memenuhi kebutuhan produksi yang } \\
\text { menghasilkan suatu barang dan jasa: } \\
\text { - pembiayaan modal kerja: untuk memenuhi } \\
\text { kebutuhan (a) peningkatan produksi, baik } \\
\text { secara kuantitatif yaitu jumlah hasil } \\
\text { produksi, maupun secara kualitatif yaitu } \\
\text { peningkatan kualitas atau mutu hasil } \\
\text { produksi dan (b) untuk keperluan } \\
\text { perdagangan atau peningkatan utility of } \\
\text { place dari suatu barang. } \\
\text { - pembiayaan investasi: untuk keperluan } \\
\text { penambahan modal guna mengadakan } \\
\text { rehabilitasi, perluasan usaha ataupun } \\
\text { pendirian proyek baru. }\end{array}$ \\
\hline 2. & Jangka waktu & a. Jangka pendek & $\leq 1$ tahun \\
\hline
\end{tabular}




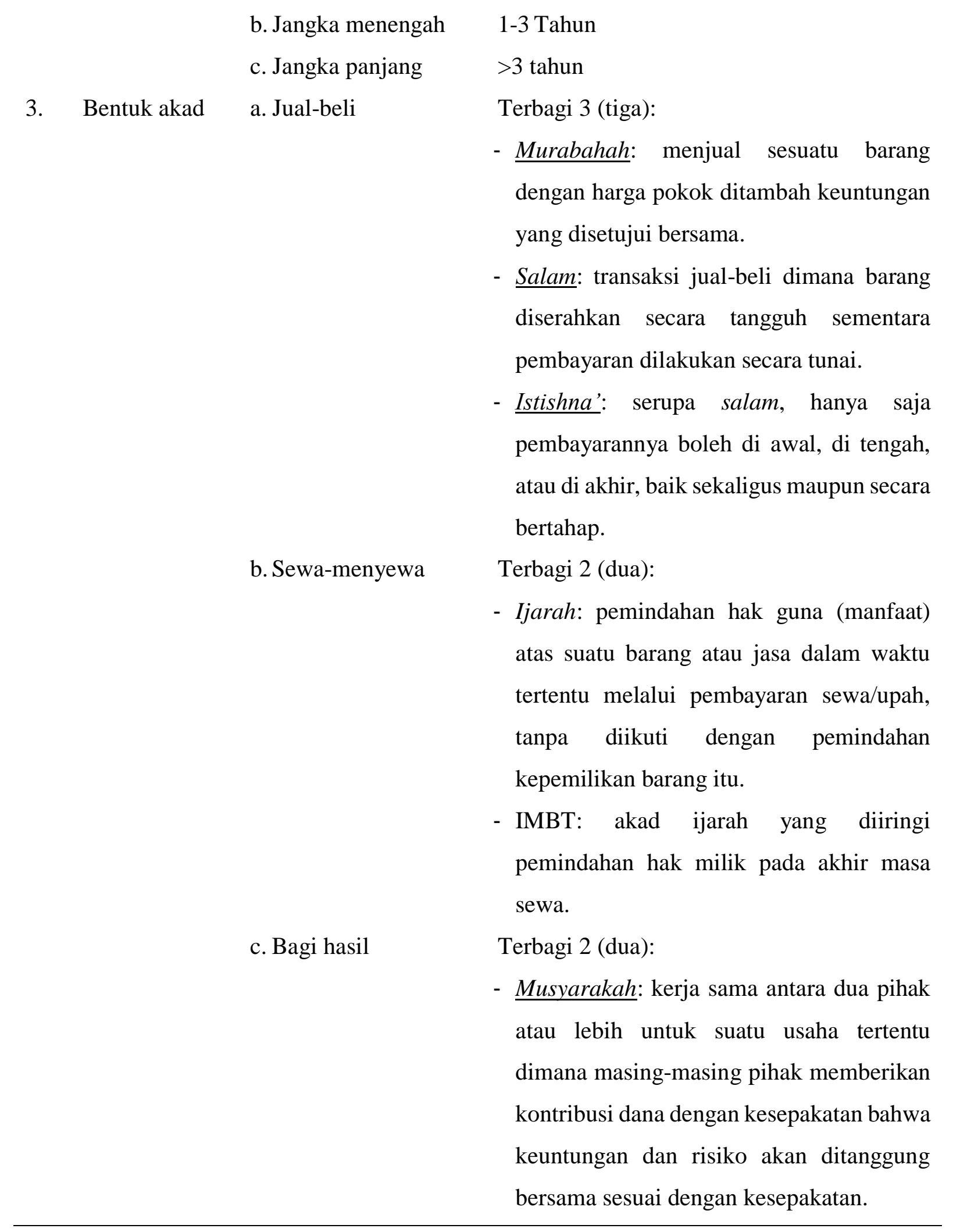


- Mudharabah: akad kerja sama usaha antara dua pihak dimana pihak pertama (shahibul maal) menyediakan seluruh (100\%) modal, sedangkan pihak lainnya menjadi pengelola.

\section{Pembiayaan Bermasalah (Non Performing Financing)}

Secara umum pembiayaan bermasalah dalam konteks Perbankan syariah adalah pembiayaan yang dalam pelaksanaan perjanjian antara Bank syariah dengan Nasabah mengalami kendala dalam arti Nasabah mengalami kesulitan atau kegagalan melakukan pembayaran kepada Bank syariah terhadap dana yang telah disalurkan oleh Bank tersebut (Zainul Arifin, 2005 : 186).

Penyebab terjadinya pembiayaan bermasalah adalah karena kesulitankesulitan keuangan yang dihadapi Nasabah. Menurut Zainul Arifin (2005, hlm. 206). Penyebab kesulitan keuangan perusahaan Nasabah dapat dibagi dalam 2 (dua) faktor berikut ini:

a. Faktor internal

Menurut Wangsawidjaja, faktor-faktor internal Nasabah yang dapat menyebabkan kredit bermasalah antara lain:

1. Penyalahgunaan kredit oleh Nasabah yang tidak sesuai dengan tujuan perolehannya.

2. Perpecahan di antara para pemilik/pemegang saham.

3. Key person dari perusahaan sakit atau meninggal dunia yang tidak dapat digantikan oleh orang lain dengan segera.

4. Tenaga ahli yang menjadi tumpuan proyek/perusahaan meninggalkan perusahaan.

5. Perusahaan tidak efisien, yang terlihat dari overhead cost yang tinggi sebagai akibat dari pemborosan.

b. Faktor eksternal

Faktor eksternal adalah faktor-faktor yang berada di luar kekuasaan manajemen perusahaan, seperti bencana alam, peperangan, perubahan 
dalam kondisi perekonomian dan perdagangan, perubahan-perubahan teknologi, dan lain-lain.

Menurut Azharsyah Ibrahim, Arinal Rahmati dalam jurnal al-Iqtishadia Volume 10 Nomor 1 2017, menyebutkan bahwa Pembiayaan bermasalah biasanya muncul secara bertahap dengan didahului oleh beberapa gejala (red flags). Menurut Mahmoeddin (2001) gejala-gejala tersebut berupa:

1. Perilaku Rekening (Account Attitudes)

Perilaku rekening nasabah dapat memberikan indikasi tentang gejala awal munculnya masalah, misalnya saldo rekening sering mengalami overdraf, saldo giro ratarata menurun, terjadi penurunan saldo secara drastis, pembayaran pokok angsuran tersendat-sendat, jadwal pencairan dana pembiayaan tidak sesuai dengan akad pembiayaan, sering mengajukan permintaan penundaan atau perpanjangan pembayaran, penyimpangan penggunaan pembiayaan, mengajukan penambahan pembiayaan, dan mengajukan penjadwalan ulang pembiayaan.

2. Perilaku Laporan Keuangan (Financial Statement Attitudes)

Berdasarkan perilaku laporan keuangan, gejala pembiayaan bermasalah dapat berupa diantaranya, penurunan likuiditas, penurunan perputaran modal pembiayaan, peningkatan piutang, penurunan perputaran persediaan, penurunan rasio aktiva lancar terhadap aktiva total, penurunan aktiva tetap, penjualan meningkat namun laba menurun, debt equity ratio meningkat, utang jangka panjang meningkat tajam, muncul hutang dari bank lain, rasio keuntungan terhadap aset menurun, laporan keuangan sering terlambat, laporan keuangan tidak diaudit, persentase laba terhadap aktiva menurun, laporan keuangan direkayasa, harga penjualan terlalu rendah dan berada di bawah titik impas.

3. Perilaku Kegiatan Bisnis (Business Activities Attitudes)

Dalam kategori ini, gejala pembiayaan bermasalah ditandai dengan penurunan supply barang, hubungan dengan pelanggan memburuk, 
harga jual terlampau rendah, kehilangan hak sebagai distributor, kehilangan pelanggan utama, mulai terlibat spekulasi bisnis, hubungan dengan bank semakin renggang, enggan dikunjungi, keterlibatan dengan usaha lain, ada informasi negatif dari pihak lain, ada klaim dari pihak ketiga, ada pemogokan buruh, nilai agunan menurun, nasabah alih usaha pokok, mencari pinjaman baru.

4. Perilaku Nasabah (Custumer Attitudes)

Gejala pembiayaan bermasalah yang muncul dalam kategori diantaranya: kesehatan nasabah memburuk, terjadi sengketa rumah tangga, telepon dari bank sering tidak dijawab, nasabah mempunyai kegiatan tertentu, dan lain-lain.

Pembiayaan bermasalah dalam Perbankan syariah diistilahkan dengan non performing financing atau disingkat NPF. Pembiayaan yang termasuk golongan NPF adalah pembiayaan dengan kolektibilitas Kurang Lancar (KL, kolektibilitas 3), Diragukan (D, kolektibilitas 4), dan Macet (M, kolektibilitas 5). Sesuai aturan OJK penetapan golongan NPF dilakukan berdasarkan penilaian terhadap 3 (tiga) faktor sebagai berikut:

1. Prospek usaha

Penilaian terhadap prospek usaha meliputi penilaian terhadap komponenkomponen sebagai berikut:

a. Potensi pertumbuhan usaha.

b. Kondisi pasar dan posisi Nasabah dalam persaingan.

c. Kualitas manajemen dan permasalahan tenaga kerja.

d. Dukungan dari group atau afiliasi.

e. Upaya yang dilakukan Nasabah dalam rangka memelihara lingkungan hidup.

2. Kinerja (performance) Nasabah

Penilaian kinerja Nasabah dilakukan terhadap komponen-komponen berikut:

a. Perolehan laba. 
b. Struktur permodalan.

c. Arus kas.

d. Sensitivitas terhadap risiko pasar.

3. Kemampuan membayar

Penilaian terhadap kemampuan membayar meliputi penilaian terhadap komponen-komponen berikut:

a. Ketepatan pembayaran pokok dan margin/bagi hasil/ujrah. ---> (controllable factor)

b. Ketersediaan dan keakuratan informasi keuangan Nasabah.

c. Kelengkapan dokumentasi pembiayaan.

d. Kepatuhan terhadap akad pembiayaan.

e. Kesesuaian penggunaan dana.

f. Kewajaran sumber pembayaran kewajiban.

Kedua faktor penilaian pertama yakni prospek usaha dan kinerja (performance) Nasabah merupakan faktor penilaian yang bersifat kualitatif yakni faktor yang sulit dikontrol (uncontrollable factor). Sementara faktor ketiga adalah faktor penilaian bersifat kuantitatif yang dapat diperhitungkan terutama terkait aspek ketepatan pembayaran angsuran pokok dan marjin/bagi hasil/ujrah .

Penetapan golongan kualitas pembiayaan bermasalah berdasarkan faktor kuantitatif dibedakan menurut jenis akad pembiayaan yang diatur oleh OJK sebagai berikut:

\begin{tabular}{llllll}
\hline No. Jenis Akad & Kriteria & Kurang Lancar & Diragukan (D) & Macet (M) \\
& Pembiayaan & Penilaian & $($ KL) & \\
\hline 1. & Bagi Hasil & Terdapat & Terdapat tunggakan & Terdapat & Terdapat tunggakan \\
& pembayaran & AP $>90$ hari s.d. tunggakan AP $>$ AP > 180 hari atau \\
& angsuran & 120 hari, atau 120 hari s.d. 180 terdapat tunggakan \\
& pokok & terdapat tunggakan hari atau terdapat pelunasan pokok $>$ \\
& & pelunasan pokok $>$ tunggakan & 90 hari setelah jatuh \\
& & 30 hari s.d. 60 hari pelunasan pokok $>$ tempo; dan/atau \\
& & setelah jatuh tempo; 60 hari s.d. 90 hari & \\
& & dan/atau
\end{tabular}




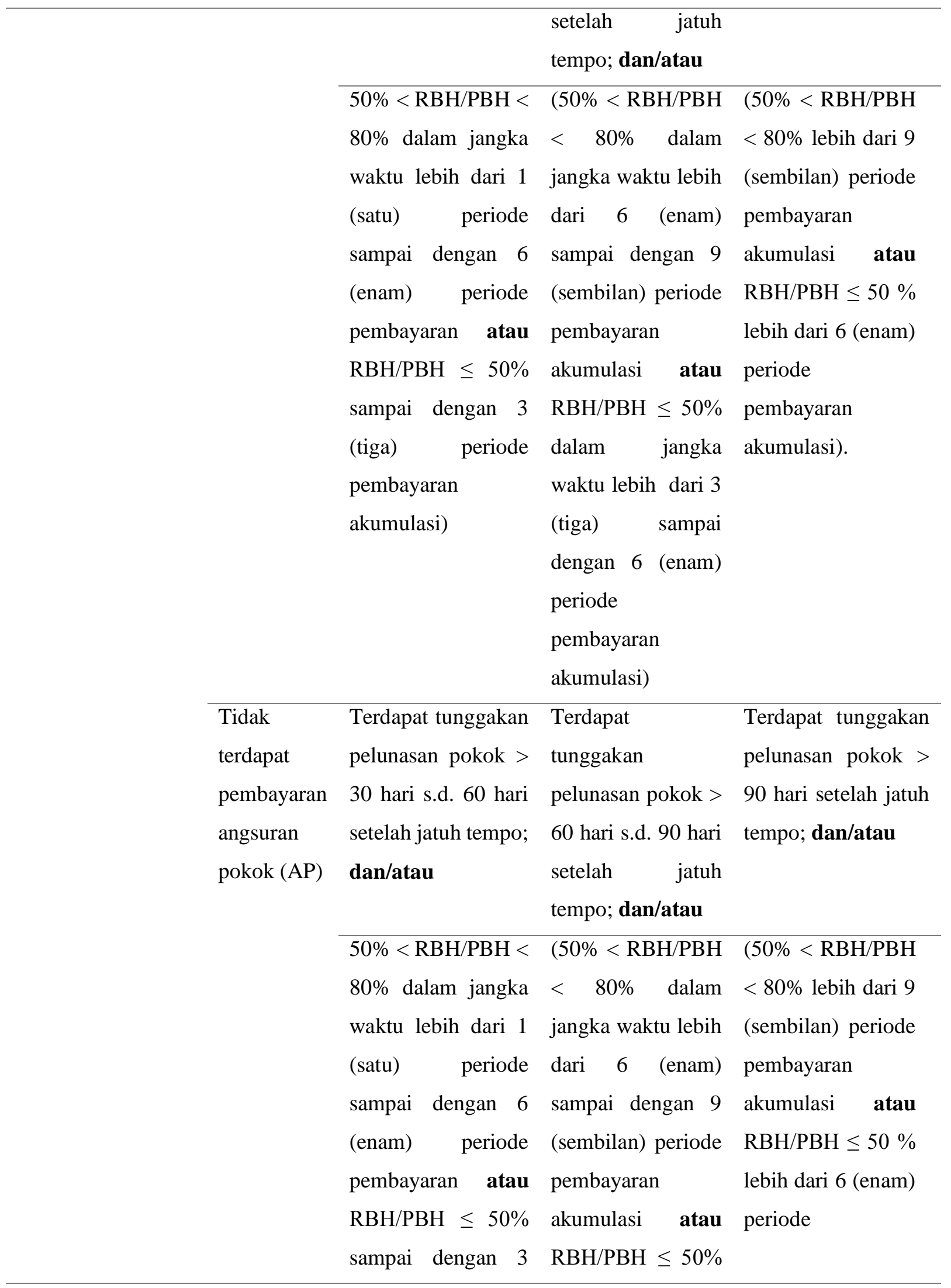




\begin{tabular}{|c|c|c|c|c|c|}
\hline & & & $\begin{array}{l}\text { (tiga) periode } \\
\text { pembayaran } \\
\text { akumulasi) }\end{array}$ & $\begin{array}{lr}\text { dalam } & \text { jangka } \\
\text { waktu lebih } & \text { dari } 3 \\
\text { (tiga) } & \text { sampai } \\
\text { dengan } 6 & \text { (enam) } \\
\text { periode } & \\
\text { pembayaran } \\
\text { akumulasi) }\end{array}$ & $\begin{array}{l}\text { pembayaran } \\
\text { akumulasi). }\end{array}$ \\
\hline 2. & $\begin{array}{l}\text { Jual-Beli dan } \\
\text { Pinjam- } \\
\text { meminjam }\end{array}$ & $\begin{array}{l}\text { Ketepatan } \\
\text { pembayaran } \\
\text { pokok dan } \\
\text { margin }\end{array}$ & $\begin{array}{l}\text { Terdapat tunggakan } \\
\text { pembayaran } \\
\text { angsuran pokok } \\
\text { dan/atau margin > } \\
90 \text { hari s.d. } 180 \text { hari }\end{array}$ & $\begin{array}{l}\text { Terdapat } \\
\text { tunggakan } \\
\text { pembayaran } \\
\text { angsuran pokok } \\
\text { dan/atau margin > } \\
180 \text { hari s.d. } 270 \\
\text { hari }\end{array}$ & $\begin{array}{l}\text { Terdapat } \\
\text { tunggakan } \\
\text { pembayaran } \\
\text { angsuran pokok } \\
\text { dan/atau margin > } \\
270 \text { hari }\end{array}$ \\
\hline 3. & $\begin{array}{l}\text { Sewa- } \\
\text { menyewa }\end{array}$ & $\begin{array}{l}\text { Ketepatan } \\
\text { pembayaran } \\
\text { sewa }\end{array}$ & $\begin{array}{l}\text { Terdapat tunggakan } \\
\text { pembayaran sewa > } \\
90 \text { hari s.d. } 180 \text { hari }\end{array}$ & $\begin{array}{l}\text { Terdapat } \\
\text { tunggakan } \\
\text { pembayaran sewa } \\
>180 \text { hari s.d. } 270 \\
\text { hari }\end{array}$ & $\begin{array}{l}\text { Terdapat } \\
\text { tunggakan } \\
\text { pembayaran sewa } \\
>270 \text { hari }\end{array}$ \\
\hline
\end{tabular}

\section{METODE PENELITIAN}

Penelitian ini bersifat kajian kepustakaan (library research) dengan cara mengumpulkan beberapa literatur, mendeskripsikan, dan menganalisa untuk diambil kesimpulan terhadap objek yang diteliti. Penelitian ini merupakan penelitian deskriptif kualitatif. Analisa kualitatif adalah apabila data yang telah dikumpulkan Peneliti tersebut jumlahnya sedikit, bersifat monografis, atau berwujud kasus-kasus, maka analisisnya adalah analisis kualitatif (Hidayat Syah, 2010: 159). Deskriptif yaitu metode penelitian yang digunakan untuk menemukan pengetahuan yang seluas-luasnya terhadap objek penelitian pada suatu masa tertentu. 
Objek penelitian ini adalah penyelesaian pembiayaan bermasalah dengan subjek penelitian adalah referensi/literatur-literatur yang berkaitan dengan pembiayaan bermasalah pada Bank Syariah. Data yang digunakan bersumber dari data primer dan data sekunder. Data primer adalah yang data diperoleh secara langsung yang dikumpulkan dari situasi aktual (Silalahi, 2010: 290). Sedangkan data sekunder yaitu data yang dikumpul dari tangan kedua atau dari sumber lain yang tersedia sebelum penelitian dilakukan (Silalahi, 2010: 291). Data yang diperoleh pada penelitian ini dilakukan melalui studi pustaka dan data yang berkaitan dengan objek penelitian.

Teknik pengumpulan data adalah kajian pustaka atau literature, oleh karena itu penelitian ini merupakan penelitian kajian pustaka (library research). Penelitian kajian pustaka merupakan penelitian yang berusaha menghimpun data dari khazanah literatur dan menjadikan dunia teks sebagai objek utama analisisnya.

\section{PEMBAHASAN}

Pembiayaan Bermasalah adalah pembiayaan yang menurut kualitasnya didasarkan atas resiko kemungkinan terhadap kondisi dan kepatuhan Nasabah pembiayaan dalam memenuhi kewajiban untuk membayar bagi hasil, serta melunasi pembiayaannya. Dalam menyelesaikan pembiayaan bermasalah, terlebih dahulu akan ditentukan kualitas pembiayaan, dimana kualitas pembiayaan sangat berpengaruh terhadap keputusan dalam penyelesain pembiayaan bermasalah. Berikut kategori kualitas pembiayaan: (Trisadini Usanti, Abd. Shomad, 2015: 105)

1. Lancar

Apabila pembayaran angsuran Pembiayaan dan margin dilakukan tepat waktu, tidak ada tunggakan, sesuai dengan persyaratan akad, selalu menyampaikan laporan keuangan secara teratur dan akurat, secara dokumentasi perjanjian piutang lengkap dan pengikatan agunan kuat.

2. Dalam Perhatian Khusus

Apabila terdapat tunggakan pembayaran angsuran pokok dan atau margin pembiayaan sampai dengan 90 hari. Akan tetapi selalu menyampaikan 
laporan keuangan secara teratur dan akurat, dokumentasi perjanjian piutang lengkap dan pengikatan agunan kuat.

3. Kurang Lancar

Apabila terdapat tunggakan pembiayaan angsuran pokok dan atau margin yang telah melewati 90 hari sampai 180 hari, penyampaian laporan keuangan tidak secara teratur dan meragukan, dokumentasi perjanjian piutang kurang lengkap dan pengikatan agunan kuat. Terjadi pelanggaran terhadap persyaratan pokok perjanjian piutang, dan berupaya melakukan perpanjangan piutang untuk menyembunyikan kesulitan keuangan.

4. Diragukan

Terjadi tunggakan pembiayaan angsuran pokok atau margin yang telah melewati 180 hari sampai dengan 270 hari. Nasabah tidak menyampaikan informasi keuangan atau tidak dapat dipercaya, dokumentasi perjanjian piutang tidak lengkap dan pengikatan agunan lemah serta terjadi pelanggaran.

5. Macet

Apabila terjadi tunggakan pembayaran angsuran pokok dan atau margin yang telah melewati 270 hari. (Veithzal Rivai, Arviyan Arifin, 2010:748)Berikut ini pengelompokan Kolektibilitas Pembiayaan Bermasalah untuk menentukan kualitas pembiayaan: (Nurnasrina, P Adiyes Putra, 2018:169)

\begin{tabular}{ccc}
\hline $\begin{array}{c}\text { Lama } \\
\text { Tunggakan/Hari }\end{array}$ & Kolektibilitas & Keterangan \\
\hline 0 & 1 & Lancar \\
1-90 Hari & 2 & Dalam perhatian Khusus \\
$91-120$ hari & 3 & Kurang Lancar \\
121-180 hari & 4 & Diragukan \\
$>180$ hari & 5 & Macet \\
\hline
\end{tabular}

Bila dilihat dari kolektibilitasnya, NPF adalah pembiayaan-pembiayaan yang telah mulai tidak dapat memenuhi kewajibannya kepada Bank sesuai 
kesepakatan yang telah disetujui semula dengan kategori kolektibilitas (kol) Kurang Lancar (KL, kol 3), Diragukan (D, kol 4), atau macet (M, kol 5).

Dalam penyelesaian Pembiayaan bermasalah, Bank syariah dapat melakukan upaya-upaya penyelesaian pembiayaan bermasalah sebagai berikut:

\section{Restrukturisasi Pembiayaan}

Kata "restrukturisasi" tak akan muncul tanpa ada kata "strukturisasi" atau "struktur" yang mendahului terjadinya sesuatu. Dengan kata lain restrukturisasi berlaku setelah adanya struktur itu sendiri. Struktur menurut bahasa adalah 1) cara sesuatu disusun atau dibangun; susunan; bangunan; 2) yang disusun dengan pola tertentu; 3) pengaturan unsur atau bagian suatu benda; 4) ketentuan unsur-unsur dari suatu benda; dan 5) pengaturan pola dalam bahasa secara sintagmatis.

Restrukturisasi secara bahasa berarti penataan kembali (supaya struktur/tatanannya baik). (Pusat Bahasa Departemen Pendidikan Nasional RI, 2008:. 1170), Jika dikaitkan dengan pembiayaan, maka restrukturisasi pembiayaan menurut istilah adalah upaya yang dilakukan Bank dalam rangka membantu Nasabah agar dapat menyelesaikan kewajibannya. (Yusak Laksmana, 2009:256). Restrukturisasi pembiayaan adalah salah satu upaya yang dilakukan Bank dalam kegiatan usaha penyaluran pembiayaan agar Nasabah dapat memenuhi kewajibannya kepada Bank. Restrukturisasi pembiayaan adalah upaya yang dilakukan Bank dalam rangka membantu Nasabah agar dapat menyelesaikan kewajibannya, antara lain melalui penjadwalan kembali (rescheduling), persyaratan kembali (reconditioning), dan penataan kembali (restructuring). (A. Wangsawidjaja Z, 2012:447)

Bank Indonesia melalui Peraturan Bank Indonesia (PBI) Nomor 10/18/PBI/2008 yang disempurnakan dengan PBI Nomor 13/9/PBI/2011 tentang Perubahan atas Peraturan Bank Indonesia Nomor 10/18/PBI/2008 tentang Restrukturisasi Pembiayaan bagi Bank Syariah dan Unit Usaha Syariah mendefenisikan restrukturisasi pembiayaan adalah upaya yang dilakukan Bank dalam rangka membantu Nasabah agar dapat menyelesaikan kewajibannya, antara lain melalui: 
a. Penjadwalan kembali (rescheduling), yaitu perubahan jadwal pembayaran kewajiban Nasabah atau jangka waktunya. Suatu tindakan yang diambil dengan cara memperpanjang jangka waktu angsuran. Dalam hal ini si debitur diberikan keringanan dalam masalah jangka waktu pembayaran kredit, misalnya perpanjangan jangka waktu kredit dari 6 bulan menjadi satu tahun sehingga si debitur mempunyai waktu yang lebih lama untuk mengembalikannya. (Kasmir, 2002: 130)

b. Persyaratan kembali (reconditioning), perubahan sebagian atau seluruh persyaratan pembiayaan, antara lain perubahan jadwal pembayaran, jumlah angsuran, jangka waktu dan/atau pemberian potongan sepanjang tidak menambah sisa kewajiban Nasabah yang harus dibayarkan kepada Bank.

c. Penataan kembali (restructuring), yaitu perubahan persyaratan pembiayaan tidak terbatas pada rescheduling atau reconditioning, antara lain meliputi: 1) Penambahan dana fasilitas pembiayaan Bank.

1) Konversi akad pembiayaan.

2) Konversi pembiayaan menjadi surat berharga syariah berjangka waktu menengah. Surat berharga syariah berjangka menengah adalah surat bukti investasi berdasarkan prinsip syariah yang lazim diperdagangkan di pasar uang dan/atau pasar modal berjangka waktu 3 (tiga) sampai 5 (lima) tahun dengan menggunakan akad mudharabah atau musyarakah.

3) Konversi pembiayaan meliputi penyertaan modal sementara pada perusahaan Nasabah. Penyertaan modal sementara adalah penyertaan modal BUS atau UUS, antara lain berupa pembelian saham dan/atau konversi pembiayaan menjadi saham dalam perusahaan Nasabah untuk mengatasi kegagalan penyaluran dana dan/atau piutang dalam jangka waktu tertentu sebagaimana dimaksud dalam ketentuan Bank Indonesia yang berlaku.

Penjadwalan kembali (rescheduling), yaitu perubahan jadwal pembayaran kewajiban Nasabah atau jangka waktunya. (Tim Redaksi 
Fokusmedia, 2009: 296). Suatu tindakan yang diambil dengan cara memperpanjang jangka waktu angsuran. Dalam hal ini debitur diberikan keringanan dalam masalah jangka waktu pembayaran pembiayaan, misalnya perpanjangan jangka waktu pembiayaan dari 6 (enam) bulan menjadi 1 (satu) tahun sehingga debitur mempunyai waktu yang lebih lama untuk mengembalikannya.

Dalam hal pembiayaan sebagai produk pada suatu Bank syariah Restrukturisasi dalam pembiayaan adalah pembiayaan yang disusun dengan pola tertentu, memperhatikan ketentuan-ketentuan dan syarat-syarat yang berlaku, dikemas dengan akad tertentu, diikat berdasarkan ketentuan yang berlaku pula, dan dengan asumsi bahwa tidak ada faktor internal dan/atau eksternal lain yang mempengaruhi seperti akibat krisis, perubahan kebijakan pemerintah, perubahan manajemen internal perusahaan debitur, dan lain-lain. Dengan susunan/pola yang telah dibangun tersebut diharapkan pembiayaan tersebut menjadi sesuatu yang berjalan baik, tepat, aman, dan bernilai baik bagi debitur/Nasabah maupun bagi Bank pemberi pembiayaan.

\section{Dasar Hukum Restrukturisasi}

Tujuan Bank syariah melakukan restrukturisasi pembiayaan adalah dalam rangka membantu nasabah agar dapat menyelesaikan kewajibannya. Hal ini sejalan dengan konsep Islam dan dasar hukum restrukturisasi yang terdapat dalam Al-Qur'an yaitu dalam surah al-Baqarah ayat 280 mengenai membantu meringankan beban orang yang berhutang:

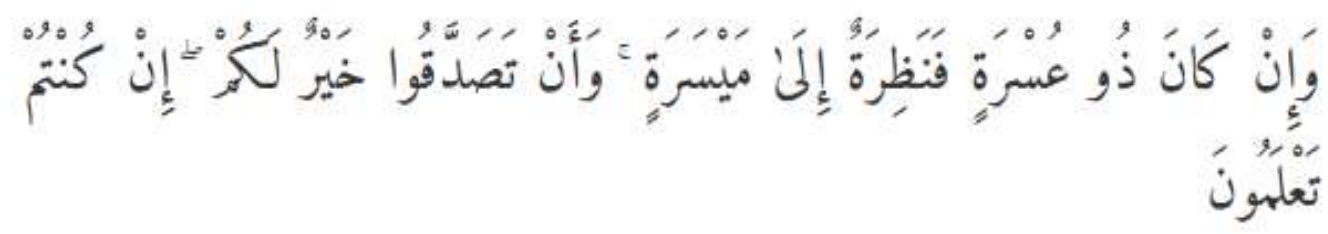

Artinya: Dan jika (orang yang berhutang itu) dalam kesukaran, maka berilah tangguh sampai dia berkelapangan. Dan menyedekahkan (sebagian atau semua utang) itu, lebih baik bagimu, jika kamu mengetahui. (Q.S Surat AlBaqarah ayat: 280) 
Pada sebuah hadits Rasulullah saw. bersabda:

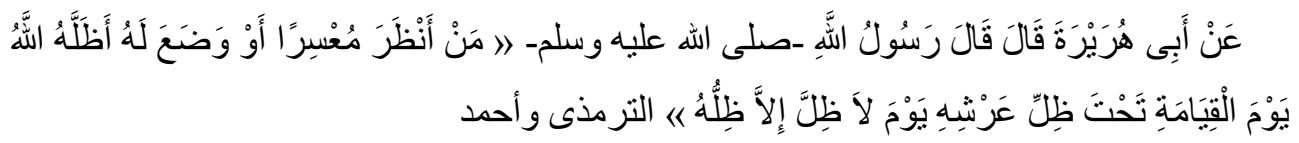

Artinya: Dari Abu Hurairah RDA, ia berkata : Rasulullah SAW telah bersabda, barang siapa memberikan tangguh kepada orang berhutang yang dalam kesulitan atau membebaskannya dari hutang tersebut, Allah akan memberikan pernaungan di bawah naungan Arasynya pada hari di mana tidak ada naungan kecuali hanya naungan Allah (HR. Tirmizi dan Ahmad). (Abu 'Isa Muhammad bin Isa at Tirmizi, Sunan at-Tirmizi, 599).

\section{Fatwa DSN (Dewan Syariah Nasional)}

Dalam pelaksanaan restrukturisasi Bank harus juga mengacu pada fatwa yang dikeluarkan oleh Dewan Syariah Nasional. Fatwa tersebut adalah:

1. Tidak mengubah akad: landasan fiqh restrukturisasi: fatwa DSN No. 46/DSN/MUI/II/2005 tentang pedoman tagihan murabahah (al-khasm fi al-murabahah) dan fatwa DSN No. 47/DSN/MUI/II/2005 tentang penyelesaian piutang murabahah bagi Nasabah tidak mampu bayar.

2. Mengubah akad: landasan fiqh restrukturisasi: Fatwa DSN No. 48/DSN/MUI/2005, tentang penjadwalan kembali tagihan murabahah dan Fatwa DSN No. 49/DSN/MUI/2005 tentang konversi akad murabahah.

\section{Ketentuan Restrukturisasi}

Restrukturisasi pembiayaan dilakukan dengan mengacu pada ketentuan-ketentuan sebagai berikut:

a. Restrukturisasi pembiayaan hanya dapat dilakukan untuk Nasabah yang memenuhi kriteria sebagai berikut; Nasabah mengalami penurunan kemampuan pembayaran, Nasabah memiliki prospek usaha yang baik dan mampu memenuhi kewajiban setelah restrukturisasi.

b. Berdasarkan PBI No. 10/18/PBI/2008 pada Pasal 5 ayat (2) restrukturisasi pembiayaan hanya dapat dilakukan untuk pembiayaan dengan kualitas 
kurang lancar, diragukan, dan macet (kolektibilitas 3, 4, dan 5). Namun kebijakan ini berubah sesuai PBI No. 13/9/PBI/2011. Meskipun pada PBI No. 13/9/PBI/2011 tersebut tidak dituliskan secara eksplisit dalam Pasal 5, namun dalam Pasal 6 ayat (1) disebutkan bahwa restrukturisasi untuk pembiayaan dengan kualitas lancar atau dalam perhatian khusus hanya dapat dilakukan 1 (satu) kali. Dengan demikian berdasarkan PBI No. 13/9/PBI/2011 ini restrukturisasi dapat dilakukan terhadap pembiayaan dengan kualitas pembiayaan golongan lancar dan dalam perhatian khusus selain golongan kurang lancar, diragukan, dan macet yang telah diatur sebelumnya.

c. Restrukturisasi pembiayaan wajib didukung dengan analisis dan buktibukti yang memadai serta terdokumentasi dengan baik.

\section{Kebijakan dan Prosedur Restrukturisasi Pembiayaan}

Kebijakan dan prosedur restrukturisasi pembiayaan mencakup paling kurang hal-hal berikut:

a. Penetapan satuan kerja khusus untuk menangani restrukturisasi pembiayaan.

b. Penetapan limit wewenang memutus pembiayaan yang direstrukturisasi.

c. Kriteria pembiayaan yang dapat direstrukturisasi.

d. Sistem dan standard operating procedure restrukturisasi pembiayaan, termasuk penetapan penyerahan pembiayaan yang akan direstrukturisasi kepada satuan kerja khusus dan penyerahan kembali pembiayaan yang telah berhasil direstrukturisasi kepada satuan kerja pengelola pembiayaan.

1. Sistem informasi manajemen pembiayaan yang direstrukturisasi.

2. Penetapan jumlah maksimal pelaksanaan restrukturisasi pembiayaan terhadap pembiayaan yang tergolong non lancar (kurang lancar, diragukan, dan macet). 
3. BUS atau UUS melakukan penyempurnaan terhadap kebijakan dan prosedur restrukturisasi pembiayaan apabila berdasarkan hasil analisis Bank Indonesia, kebijakan dan prosedur tersebut dinilai kurang memperhatikan prinsip kehati-hatian dan/atau tidak sesuai dengan ketentuan yang berlaku. (Tim Redaksi Fokusmedia, 2009: 299).

\section{Faktor dan Kendala dalam Pelaksanaan Restrukturisasi}

Berikut kriteria/faktor yang memengaruhi keberhasilan pelaksanaan restrukturisasi pembiayaan bermasalah: 1) Itikad baik Nasabah, Nasabah bersikap kooperatif terhadap Bank untuk menyelesaikan pembiayaan bermasalahnya. Misalnya memenuhi panggilan Bank, menyediakan waktu untuk dikunjungi, menyerahkan data yang diminta oleh Bank, dan memberikan imformasi yang benar kepada Bank, 2) Mempunyai itikad baik dalam hubungan dengan pihak Bank, termasuk untuk menyelesaikan pembiayaan bermasalah, misalnya memberikan usulan yang positif tentang penyelesaian pembiayaan bermasalah, 3) Tidak mempunyai masalah internal bersifat serius yang mungkin akan menggangu proses penyelamatan pembiayaan, misalnya manajemen dan organisasi perusahan tidak mengalami perubahan dan tidak terdapat konflik internal dengan pekerja/karyawan, 4) Secara umum usaha atau kegiatan Nasabah masih berjalan dan mempunyai prospek misalnya produksi masih berjalan, bahan baku dan pengadaannya masih terjamin, dan pelanggan masih ada, 5) Objek jaminan pembiayaan masih dikuasi oleh Bank secara baik, misalnya jaminan telah diikat secara sempurna sesuai dengan ketentuan lembaga jaminan hak tangungan, jaminan fidusia, hipotik atau gadai. Dokumen-dokumen pengikatan jaminan dan dokumen-dokumen jaminan dikuasi oleh Bank, 6) Telah mengajukan permohonan penyelamatan pembiayaan kepada Bank. 


\section{Penyelesaian Melalui Jaminan}

Jika Restrukturisasi pembiaayan seperti diatas tidak mengeluarkan Nasabah dari gagal membayar kewajibannya, maka tindakan berikutnya adalah penyelesaian melalui jaminan. ((Nurnasrina, P Adiyes Putra, 2018:174). Penyelesaian melalui jaminan bila berdasarkan hasil evaluasi ulang pembiayan, Nasabah sudah tidak memiliki prospek usaha dan Nasabah tidak cooperative untuk menyelesaikan pembiayaan. Penyelesaian melalui jaminan dapat dilakukan dengan cara non litigasi dan litigasi. Penyelesaian dengan cara non ligitasi merupakan penyelesaian pembiayaan bermasalah tanpa melalui jalur hukum dan lebih mengedepankan musyawarah mufakat. Penyelesaian dengan cara ini dilakukan dengan off set dan musyawarah. Off set adalah penyelesaian pembiayaan melalui penyerahan jaminan secara sukarela oleh Nasabah kepada Bank, sebagai upaya penyelesaian pembiayaan.Penyelesaian dengan ligitasi merupakan penyelesaian pembiayaan bermasalah lewat jalur hukum yang berlaku. Tahapan pertama adalah dengan pengajuan dan pemberian somasi hukum kepada Nasabah. Somasi ini dilakukan apabila berdasarkan hasil evaluasi ulang yang dilakukan Bank, Nasabah sudah tidak memiliki usaha dan tidak kooperatif untuk menyelesaikan pembiayaan dari Bank, sedangkan restrukturisasi proses sudah tidak dapat dilakukan. Apabila Nasabah tetap tidak juga memenuhi kewajibannya kepada Bank, maka Bank akan melakukan upaya ligitasi termasuk dengan melakukan upaya sita jaminan ke lembaga peradilan. (Nurnasrina, P Adiyes Putra, 2018:177).

\section{Collection Agent}

Penyelesaian pembiayaan dengan collection agent dilakukan dengan menggunakan jasa pihak ketiga seperti agen/kantor hukum atau pengacara.

\section{Hapus Buku (Write Off)}

Hapus buku (write off) adalah tindakan administrasi untuk menghapus buku Nasabah yang memiliki kolektibilitas macet dari neraca sebesar total tunggakan Nasabah tanpa menghapus hak tagih kepada Nasabah. Hapus buku 
hanya dapat dilakukan terhadap pembiayaan yang memiliki kualitas pembiayaan macet atau telah diturunkan menjadi macet. Hapus buku hanya dapat dilakukan setelah dilakukan upaya yang maksimal untuk menyelesakan asset pembiayaan yang digolongkan macet. . (Nurnasrina, P Adiyes Putra, 2018:180). Penghapusan pembiayaan dengan cara hapus buku adalah penghapusan pembiayaan bermasalah dari pembukuan Bank, namun pembiayaan tersebut masih dicatat secara ekstrakomtabel.

Hapus buku tidak dapat dilakukan terhadap sebagian Pembiayaan (partial write off). Hapus buku dapat dilakukan terhadap jenis pembiayaan yang telah diklasifikasikan sebagai "Macet" atau kolektibiliti golongan V dalam versi Bank Indonesia dan memenuhi minimal salah satu kriteria di bawah ini :

a. Karakter nasabah buruk atau tidak ada kemampuan untuk membayar

b. Semua usaha penyelamatan pembiayaan telah gagal dan pengembalian di kemudian hari, apabila ada, diperkirakan kecil nilainya.

c. Telah dajukan ke pengadilan / instansi negara lainnya

d. Agunan sudah tidak ada / tidak marketable / bermasalah

e. Biaya penagihan tidak sebanding dengan hasil yang diperoleh (Ubaidillah, 2018: 307).

Pembiayaan dapat dihapusbukukan (write off) jika memehui persyaratan: a) Jika Nasabah mengalami keterlambatan dalam membayar kewajiban pokok dan margin lebih dari 180 hari. b) Nasabah meninggal dunia dan tidak di cover oleh pihak asuransi sert ahli waris tidak bersedia/ tidak mampu untuk membayar sisa tunggakan Nasabah. c) Nasabah mengalami sakit akut atau cacat permanen dan tidak dapat melakukan aktifitas usaha dibuktikan dengan surat keterangan medis. d) Keberadaan Nasabah tidak diketahui dan sudah dilakukan upaya pencarian. e) Sebelum melakukan penghapus bukuan, pembiayaan wajib diubah kualitas pembiayaannya terlebih dahulu menjadi macet. 
Berdasarkan literatur - litaratur yang penulis temui, untuk mengatasi pembiayaan bermasalah pada Bank syariah ada beberapa upaya yang dapat dilakukan, baik untuk penyelamatan pembiayaan maupun penyelesaian pembiayaan. Penyelamatan pembiayaan dapat dilakukan oleh Bank syariah kepada Nasabah pembiayaan yang usaha Nasabah teersebut masih memiliki prospek yang baik dan Nasabah yang bersangkutan masih memiliki itikad yang baik untuk memenuhi kewajibannya kepada Bank. Penyelamatan pembiayaan dapat dilakukan dengan cara restrukturisasi pembiayaan. Jika usaha Nasabah dinilai oleh pihak Bank tidak memiliki prospek usaha kedepannya dan itikad baik Nasabah dianggap kurang, maka Bank syariah dapat melakukan penyelesaian pembiayaan dengan cara penyelesaian melalui sita barang jaminan.

\section{KESIMPULAN}

Bank syariah tentu berharap bahwa pembiayaan-pembiayaan yang telah disalurkannya akan menjadi pembiayaan yang lancar, sehat, dan bermanfaat buat penerimanya. Namun harapan tersebut tidak selamanya akan terwujud. Adakalanya pembiayaan yang diberikan menjadi pembiayaan yang bermasalah, dimana Nasabah tidak mampu membayar kewajibannya sehingga terjadi tunggakan. Banyak faktor yang memengaruhi terjadinya pembiayaan bermasalah baik yang bersifat internal Nasabah maupun eksternal. Yang terpenting, Bank dapat melakukan langkah penyelamatan ketika Nasabah sudah menunjukkan gejala bermasalah, sebelum pembiayaan tersebut benar-benar menjadi pembiayaan yang bermasalah (macet).

Dalam penyelesaian pembiayaan bermasalah pada Bank syariah, Bank dapat melakukan upaya-upaya penyematan dan penyelesain pembiayaan dengan cara Restrukturisasi. restrukturisasi yang dapat dilakukan adalah Penjadwalan kembali (rescheduling), Persyaratan kembali (reconditioning), Penataan kembali (restructuring), Penjadwalan kembali (rescheduling). Penyelesaian melalui jaminan. .Collection Agent dan Hapus Buku (write off). 


\section{DAFTAR PUSTAKA}

Adiwarman A Karim, Bank Islam Analisis Fiqh dan Keuangan, Jakarta: PT. Raja Grafindo Persada, 2004 Edisi Ketiga.

Adirmana Karim, Ekonomi Islam suatu kajian kontemporer, Jakarta: Gema Insani, 2001, cet I.

Ascarya, Akad \& Produk Bank Syariah, Jakarta: PT. Raja Grafindo Persada, 2007, Cet. ke-1.

A. Wangsawidjaja Z., Pembiayaan Bank Syariah, Jakarta: PT. Gramedia Pustaka Utama, 2012, cet. ke-1.

Departeman Agama RI, al-Qur'an dan Terjemahannya, Bandung: PT. Syamil Cipta Media, 2005.

Fokusmedia, Undang-undang Ekonomi Syariah, Bandung: Fokusmedia dan IKAPI, 2009, Cet. ke-1.

Hidayat Syah, pengantar umum metodologi penelitian pendidikan pendekatan verifikatif, Pekanbaru: Suska press, 2010, cet-1.

HR. Ibnu Majah, Bab bai'u al-khiyar, Beirut:Muassasah Risalah, 1405H, jilid 2

Nurul Oktoma, Kamus Ekonomi, Surakarta: PT. Aksarra Sinergi Media, 2012.

Pusat Bahasa Departemen Pendidikan Nasional RI, Kamus Besar Bahasa Indonesia, Jakarta: PT. Gramedia, 2008, Edisi Keempat.

Sunarto Zulkifli, Panduan Praktis Transaksi Perbankan Syariah, Jakarta: Zikrul Hakim, 2003, Cet. ke-1.

Syafii Antonio, Bank Syariah dari Teori ke Praktik, Jakarta: Gema Insani, 2001, cet. ke-1.

Tim Redaksi Fokusmedia, Undang-undang Ekonomi Syariah, Bandung: Fokusmedia, 2009, Cet. Januari 2009.

Ubaidillah, Pembiayaan Bermasalah pada Bank Syariah: Strategi Penanganan dan Penyelesaiannya, Jurnal el-Jizya Vol. 6 No. 2 Juli-Desember 2018, http://ejournal.iainpurwokerto.ac.id/index.php/eljizya/article/view/2042/136 3, diakses 12 April 2020, 17:26:14 WIB.

Veithzal Rivai, dkk., Bank and Financial Institution Management, (Jakarta: PT. RajaGarafindo Persada, 2007), Edisi 1.

Veithzal Riva'I dan Arviyan Arifin, Islamic Banking, (Jakarta: Bumi Aksara, 2010), Cet. Pertama.

Yusak Laksmana, Panduan Praktis Account Officer Bank Syariah, Jakarta: PT. Elex Media Computindo, 2009, Cet. ke-1.

Zainul Arifin, Dasar-dasar Manajemen Bank Syariah, Jakarta: Pustaka Alvabet, 2005 , cet. ke-3. 